\title{
Changing land-use based on location in landscape affects catchment water yield
}

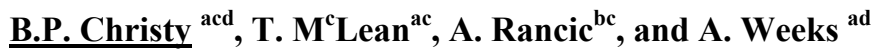 \\ ${ }^{a}$ Future Farming Systems Research, Department Primary Industries, Rutherglen, Vic 3685 AUSTRALIA. \\ ${ }^{\mathrm{b}}$ Department of Environment and Climate Change, Wagga Wagga, NSW 2650 AUSTRALIA. \\ ${ }^{c}$ Future Farm Industries CRC, University of Western Australia, WA 6009 AUSTRALIA \\ ${ }^{d}$ eWater CRC, University of Canberra, ACT 2601 AUSTRALIA \\ Email: Brendan.Christy@dpi.vic.gov.au
}

\begin{abstract}
The Future Farm Industries CRC (FFI CRC) is focused on increasing the perenniality of landuse within catchments to improve natural resource management outcomes, while increasing profitability. A potential negative consequence of increasing perenniality is a decrease in catchment water yield. This paper considers the impact of some key FFI CRC land-use change strategies on catchment water yield. These strategies are plantation forestry and increasing perenniality of pasture based on EverGraze principles (www.evergraze.com.au).
\end{abstract}

The study area for this project was the Glenelg Hopkins Region, South West Victoria, Australia; specifically the Wannon River catchment (345,477 ha). Plantation forestry was in the form of blue gums to be converted to wood pulp. The strategy to change pasture perenniality was based on EverGraze principles to ensure that CATPlus model outputs informed EverGraze activities and reinforced EverGraze outputs. EverGraze researchers along with other local farming experts helped this project focus its modeling research question to be relevant to their needs. Their questions required land-use changes at a farm scale, which reflected position in landscape (driven by whether the land was crest, slope or valley) and assess any potential impacts of increased perenniality on the filling of farm dams and wetlands within the catchment. Consideration of farm dams and wetlands was from the perspective of stock water supply and maintaining wetland health during extended dry periods, hence the modeling solution required greater spatial resolution than comparable dam models like TEDI whose primary design focus is the impact of farm dams on subsequent stream flow. From an agricultural perspective, reliable stock water supply via farm dams underpins the livestock grazing industry. In areas with saline groundwater, like the northern Wannon region, farm dams form the sole source of available stock water. This reliance on farm dams created concern with the expert working group that farm dams would not fill as frequently in a perennial dominated landscape.

Some of the key results were that CATPlus was able to provide an adequate stream flow prediction over time (monthly $\mathrm{CoE}>0.8$ ). Improvement in prediction over this period was achieved through accounting for gaining and losing water stores along a stream reach including dams and wetlands. The decrease in catchment water yield by tree plantations was 1.5 times that of EverGraze. In addition, a notable increase in the period when farm dams are dry only occurs in the Wannon catchment at higher levels of perennial adoption.

This paper has shown the ability of CATPlus to predict the potential impacts of increasing catchment perenniality on stream flow and water bodies such as farm dams and wetlands. Due to the hydrological complexity of landscapes, the impact on streamflow of future increased perenniality will vary across the landscape. CATPlus presents a valuable tool for investigating these potential impacts.

Keywords: CATPlus, Water yield, Farm Dams, Lucerne, Grazing. 
Christy et al., Changing land-use based on location in landscape affects catchment water yield.

\section{INTRODUCTION}

The Future Farm Industries CRC (FFI CRC) is focused on increasing the perenniality of land-use within catchments to improve natural resource management outcomes, while increasing profitability. A potential negative consequence of increasing perenniality is a decrease in catchment water yield. This paper considers the impact of some key FFI CRC land-use change strategies on catchment water yield. These strategies are plantation forestry and increasing perenniality of pasture based on EverGraze principles (www.evergraze.com.au).

\subsection{The Study Area}

The Wannon catchment used in this study covers an area of 345,477 hectares. It incorporates the Wannon River upstream of gauge 238228 which is located near the Henty Creek convergence (Figure 1). Geologically, the catchment may be split into two functional groups. First, the basalt volcanic plains with a mixture well developed drainage representing the earlier Pliocene volcanic landscapes, and Newer Volcanic lavas that formed in the Late Pliocene generally characterised by thin regolith development and poorly developed drainage. Second, the Dundas Tablelands (Casterton, Red Gum Country) characterized by undulating to rolling landscape of plains and rises, that is underlain by Palaeozoic and Mesozoic rocks

Over the past 100 years, the pasture base in South West Victoria has changed from native perennials to a mix of annuals and winter active perennials. The dominant perennial grasses sown are currently perennial rye grass on the basalt

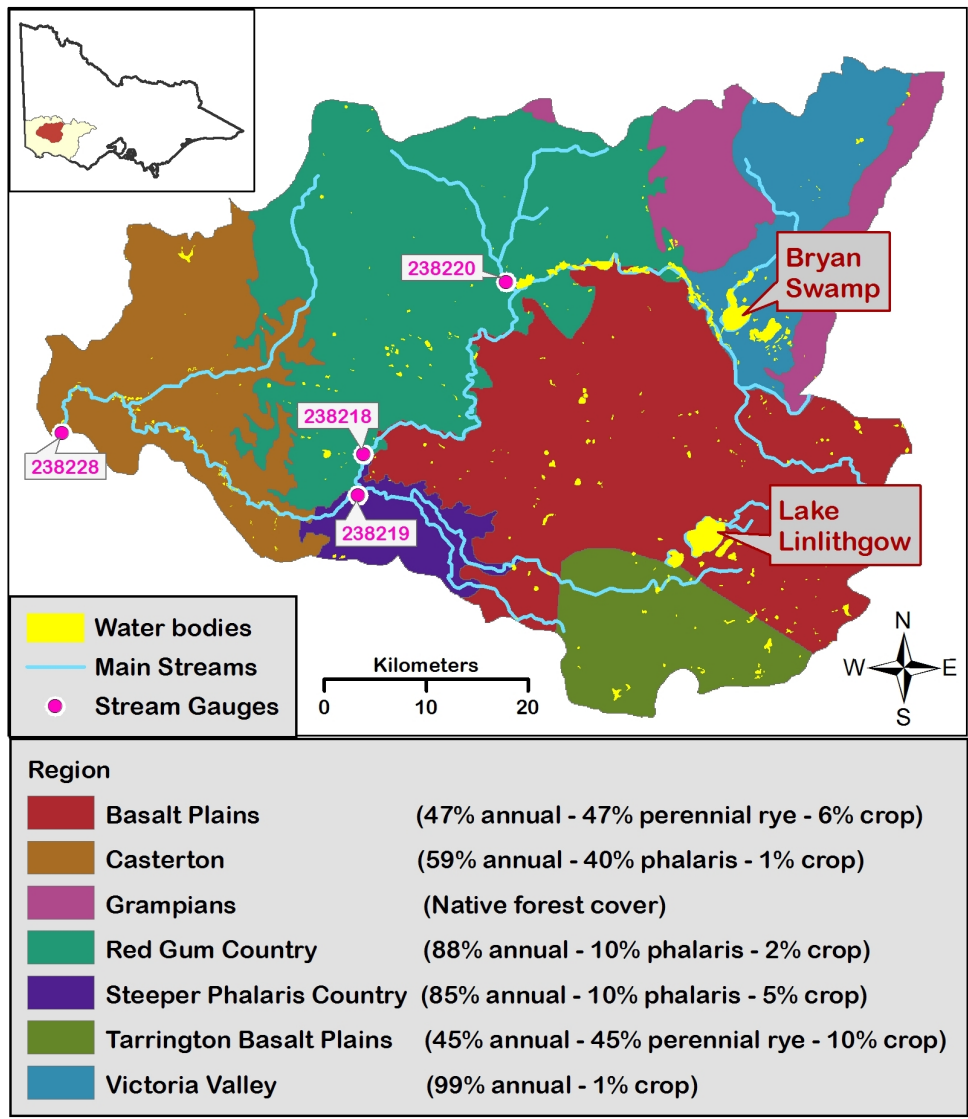

Figure 1. Location of the Wannon Catchment, Victoria. plains and phalaris in other parts of the catchment (Figure 1). However, many sown pastures contain less than $30 \%$ perennials and are dominated by annual grasses. EverGraze, a national farming system project with the aim of improving productivity with summer active perennials (Avery et al. 2009) is active in this catchment. In this catchment EverGraze increased perenniality through Lucerne, Tall Fescue, Chicory and Kikuyu. Commercial plantation forestry (blue gums) exists within the catchment, although growth of this industry has not been as great as south of the Wannon. More recently, there is also intense competition from annual cropping systems that are seen to be more profitable than traditional grazing systems. If this trend were to continue, perenniality would decrease even further.

\subsection{Objectives}

This paper aims to use CATPlus to identify potential impacts of increasing catchment perenniality on stream flow and water bodies such as farm dams and wetlands. The perennial species assessed simultaneous within the catchment include Lucerne, Tall Fescue, Rye grass and Plantation Forestry at different adoption rates to assess their impact on water yield. 
Christy et al., Changing land-use based on location in landscape affects catchment water yield.

\section{METHODOLOGY}

\subsection{Overview of Modelling Approach}

CATPlus, which has been funded by the Future Farm Industries Cooperative Research Centre (CRC), is an extension of the Catchment Analysis Tool (CAT) enabling enhanced prediction of catchment water yield to stream. It uses a range of farming models and a forest growth model to determine catchment water use, quick flow and recharge combined with CATNode, a nodal model designed to predict catchment scale stream flow. CAT has its origins in the early 2000s when the Department of Primary Industries Victoria (DPI-Vic) and the Cooperative Research Centre for Plant-based Management of Dryland Salinity provided funding for model development (Weeks et al. 2008). Initially, CAT focused on predicting the impacts of various land use scenarios on dryland salinity. Since the early 2000s, in collaboration with additional partners, CAT has grown to include additional modules that address other aspects of landscape processes. This has allowed $\mathrm{CAT}$ to respond to a broader range of land management questions than originally intended.

In functional terms, CAT links paddock-scale land use, soils, topography and climate data to catchment-scale groundwater systems and streamflows on a daily time-scale. An ensemble of crop growth and farm management models provide for the evaluation of various types of land use, land cover, and management strategies relative to their impacts in surface hydrology and landscape system dynamics. Model outputs can be produced for a variety of temporal scales - e.g., daily or monthly - and spatial scales - e.g., 1 ha pixels, individual paddocks, entire catchments. Once CAT is calibrated for a given area, it can be used to evaluate the impacts of land use change scenarios on one or more "landscape services" - e.g., salinity mitigation, clean water, carbon sequestration. The formulation of "appropriate" land use change scenarios is highly dependent on the motivation underlying the use of a modelling approach.

\subsection{Land use}

To undertake this task the project team engaged with local expert groups in Victoria to define a series of scenarios to test the impact on catchment water yield of increasing the perennial plant content within a catchment. These groups are composed of individuals and organisations that provide a wealth of information, data, and social and historical context of land-use for the study area. Engagement of these individuals resulted in support for CATPlus model outputs by individuals who have previously been sceptical of model-based approaches for catchment management. In particular, EverGraze has been targeted with EverGraze personnel providing input to ensure that CATPlus model outputs will inform EverGraze activities and reinforce EverGraze outputs.

The expert working group for this project focused the research to test land-use changes which reflect position in landscape (driven by landform considerations of crest, slope or valley) and assess any potential impacts of increased perenniality on the filling of farm dams and wetlands within the catchment. To generate land use layers to answer questions posed by the reference group the following methodologies were implemented:

- Incorporation of different tree densities within landscapes;

- Inclusion of recent forest plantations;

- Land use based on landform and soil;

- Incorporation of wetlands and dams with a connected landscape function;

All these individual steps were then amalgamated to create a dynamic land use coverage that provided the base on which scenarios have been built. In building scenarios, remnant tree cover, native pasture, urban (towns and roads), plantations and waterbodies have been left unchanged. The overall Wannon catchment includes $3 \%$ native pasture, $3 \%$ urban, $4 \%$ plantation and $2 \%$ waterbodies.

\subsection{Application of the EverGraze pasture species by landform}

To consider the effect of introducing EverGraze recommended pastures into the Wannon catchment, each cell was assessed as 'crest' or 'valley', those not categorized either way being considered 'slopes'. The EverGraze pasture system needed to be modified, as parts of the Wannon catchment are unsuitable for growing both Tall Fescue and Perennial Rye grass due to persistence problems. The appropriate species were then incorporated into the landscape according to Table 1. For each land grouping region (Figure 1) a different percentage of each species was planted to account for the landform area available for that system. 
Christy et al., Changing land-use based on location in landscape affects catchment water yield.

This is especially important for the basalt plains as $50 \%$ of the land area was from the "Slope" land class, which was planted to perennial rye grass that has a very similar water use pattern to annual ryegrass. Of the perennial land use mix being tested, Lucerne has the

Table 1. Evergraze species for each landform and region in the Wannon catchment

\begin{tabular}{|l|c|c|c|}
\hline Landscape grouping & Crest & Slope & Valley \\
\hline Basalt Plains & Lucerne & Perennial rye & Tall fescue \\
\hline Tarrington Basalts & Lucerne & Perennial rye & Tall fescue \\
\hline Steeper Country & Lucerne & Phalaris & Phalaris \\
\hline Casterton & Lucerne/Phalaris & Phalaris & Phalaris/Lucerne \\
\hline Redgum & Lucerne & Phalaris & Phalaris \\
\hline
\end{tabular}

highest potential water using ability. Since it would be unrealistic to assume that all landholders would convert their farms to these specifications, a number of adoption rates were applied. $100 \%$ adoption means that all pasture was replaced with the EverGraze options. Other adoption rates tested were 50\%, 25\% and $10 \%$. Since the location of any changes is unknown, these were applied as a combination landuse, with the Current landuse being retained over the remaining land. So, a 50\% adoption would see the percent cover from the original landuse halved, and half the applicable EverGraze pasture system percentages added

\subsection{Application of other landuse changes}

Other scenarios considered included completely replacing grazing land with lucerne pasture, annual pasture, cropping or tree plantation. The tree plantation option was also modeled with adoption rates of $100 \%, 50 \%, 25 \%$ and $10 \%$ as for the EverGraze pastures. A summary of the percentage land cover for each scenario is shown in Table 2.
Table 2 Wannon catchment - Final land cover percentages for each scenario

\begin{tabular}{|c|c|c|c|c|}
\hline Scenario & Trees & $\begin{array}{c}\text { Perennial } \\
\text { Pasture }\end{array}$ & $\begin{array}{c}\text { Annual } \\
\text { Pasture }\end{array}$ & Cropping \\
\hline Current Practice & 14 & 23 & 48 & 3 \\
\hline $100 \%$ Cropping & 14 & 0 & 0 & 74 \\
\hline $100 \%$ Annual Pasture & 14 & 0 & 74 & 0 \\
\hline $100 \%$ Lucerne Pasture & 14 & 74 & 0 & 0 \\
\hline $100 \%$ Trees & 88 & 0 & 0 & 0 \\
\hline $50 \%$ Trees & 52 & 11 & 24 & 2 \\
\hline $25 \%$ Trees & 33 & 17 & 36 & 2 \\
\hline $10 \%$ Trees & 22 & 20 & 44 & 0 \\
\hline $100 \%$ EverGraze & 14 & 74 & 0 & 1 \\
\hline $50 \%$ EverGraze & 14 & 49 & 24 & 2 \\
\hline $25 \%$ EverGraze & 14 & 36 & 36 & 2 \\
\hline $10 \%$ EverGraze & 14 & 28 & 44 & \\
\hline
\end{tabular}

\subsection{Incorporating Farm Dams and Wetlands}

Consideration of farm dams and wetlands was from the perspective of stock water supply and maintaining wetland health during extended dry periods, hence the modeling solution required greater spatial resolution than comparable dam models like TEDI (Nathan et al. 2004) whose primary design focus is the impact of farm dams on subsequent stream flow. From an agricultural perspective, reliable stock water supply via farm dams underpins the livestock grazing industry. In areas with saline groundwater, like the northern Wannon region, farm dams form the sole source of available stock water. The reliance on farm dams was the principle reason the expert working group was concerned that farm dams would not fill as frequently in a perennial dominated landscape.

Implementation of farm dams and wetlands for the expert working group required the development of a new methodology for incorporation into CATPlus. Farm dams are local water storages that usually do not appear in land use mapping and the volume of water they hold is unknown. To determine when farm dams are empty and full, there was a need to establish where in the catchment water flows into dams and other water bodies. Dam levels fluctuate as a result of runoff and overflow processes, evaporation and other extractions. Separate processes have been implemented for dams and water bodies in streamlines and farm dams excavated within paddock separate from the main stream lines. For the Wannon catchment, a spatial layer was available showing the location of farm dams (as points). Farm dam sizes are variable; hence satellite images and aerial photographs were used to assess the actual surface areas (at capacity) for a cross section of the region. The surface area-volume relationship adopted for this study was derived by McMurray (2004). 
Christy et al., Changing land-use based on location in landscape affects catchment water yield.

Large water bodies (wetlands) including large shallow lake system like Bryan Swamp and Lake Linlithgow (Figure 1) were incorporated in the land-use layer as described above. These water bodies also have filling/emptying phases. The newly developed dam and wetland processes have been applied to all scenarios.

\section{RESULTS AND DICUSSION}

\subsection{Calibration}

Stream gauge locations for the Wannon catchment are shown in Figure 1. Based on predicted monthly stream flow response at the four stream gauge locations, CATPlus was able to predict measured stream flow discharge well, with the test of coefficient of efficiency (CoE) (Nash and Sutcliffe 1970) above 0.80 for all gauges (Table 3). While a CoE of 0.6 is viewed as acceptable, a CoE of 0.8 or higher was believed to

Table 3. Summary of the Coefficient of Efficiency and Stream Flow predictions for the Wannon

\begin{tabular}{|l|c|c|c|c|}
\hline Gauge & $\mathbf{2 3 8 2 1 8}$ & $\mathbf{2 3 8 2 1 9}$ & $\mathbf{2 3 8 2 2 0}$ & $\mathbf{2 3 8 2 2 8}$ \\
\hline Period of measured daily streamflow & $1969-2008$ & $1973-2008$ & $1990-2008$ & $1973-2008$ \\
\hline Volume ratio (Calibrated/Observed) & 0.98 & 1.00 & 1.01 & 1.03 \\
\hline Coefficient of Determination $\left(\mathrm{R}^{2}\right)$ & 0.75 & 0.73 & 0.67 & 0.76 \\
\hline Coefficient of Efficiency (CoE) & 0.81 & 0.80 & 0.82 & 0.82 \\
\hline
\end{tabular}

provide a good representation of streamflow at the gauge. Volume ratio over the calibration period was reproduced with the error margin $|\varepsilon|<5 \%$ for the stream gauges.

The inclusion of the dam and wetland model improved model prediction of stream flow by CATPlus (Figure 2). Without the inclusion of the dam model the CoE for the gauge 238228 would have been 0.75 . The principle reason for the prediction improvement is due to excess water interception by dams during

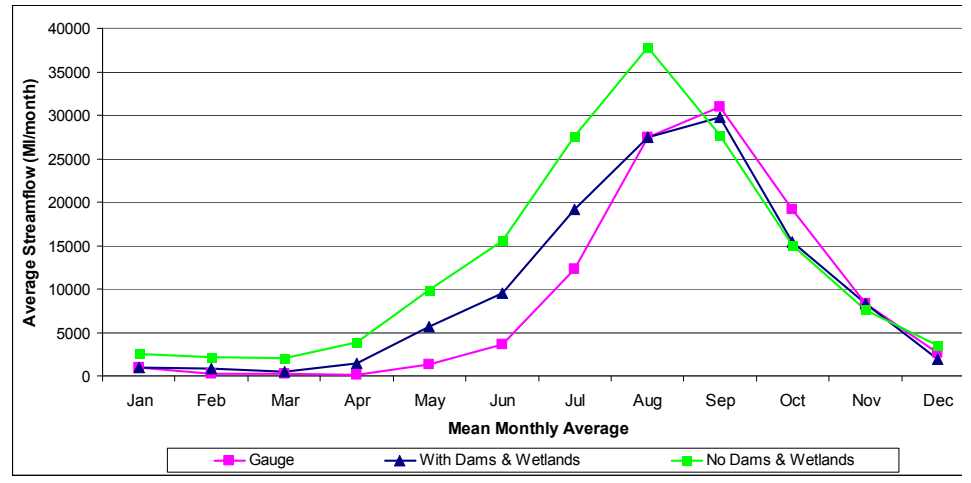

Figure 2 Average measured mean monthly stream flow at gauge 238228 and predicted stream flow with dam and wetland model included and removed the autumn early winter months improving the volume and timing of flow.

\subsection{Effect of EverGraze adoption rates and tree planting on streamflow}

Relative to current practice Figure 3 shows the change in average stream flow (1957-2009) of various land use scenarios in the Wannon catchment. The upper and lower bounds that could be achieved within the catchment by land use change are shown as red bars. Hypothetical, maximum possible upper bound (increase in stream discharge) would occur if presently cleared land were replaced by annual cropping $\mathbf{( 1 0 0 \% C r o p , ~ F i g u r e ~ 3 ) . ~ T h e ~ m o r e ~ r e a l i s t i c ~ u p p e r ~ b o u n d ~ i s ~ g i v e n ~ b y ~ t h e ~ o p t i o n ~ i n ~ w h i c h ~ o n l y ~ p r e s e n t l y ~}$ cleared land is planted by annual grass (100\% Annual). Both options plot positive, increasing flow in Wannon catchment. Various EverGraze adoption scenarios and tree planting scenarios decrease streamflow. Presented difference between realistic upper bound and lower bound (100\%Lucerne and/or 100\% Tree Plantation) represents the hydrologic maneuvering capability ("size of the bucket") for the perenniality variation within the catchment, based on the past 57 years of climatic record.

For the entire Wannon catchment a 100\% EverGraze adoption rate would reduce the flow by 37\% (from 32 $\mathrm{mm} /$ year to $20 \mathrm{~mm} /$ year) and if the tree cover was $100 \%$ the reduction of flows would be $57 \%$ (to 13 $\mathrm{mm} /$ year). For the Wannon catchment the difference in water use between Lucerne and Tree Plantations is very small. The principle reason for this small difference is that $96 \%$ of the Wannon catchment receives a mean annual rainfall between $650-720 \mathrm{~mm} /$ year. The expected difference in water use between Lucerne and Tree Plantations would be larger in catchments with greater mean annual rainfalls. 


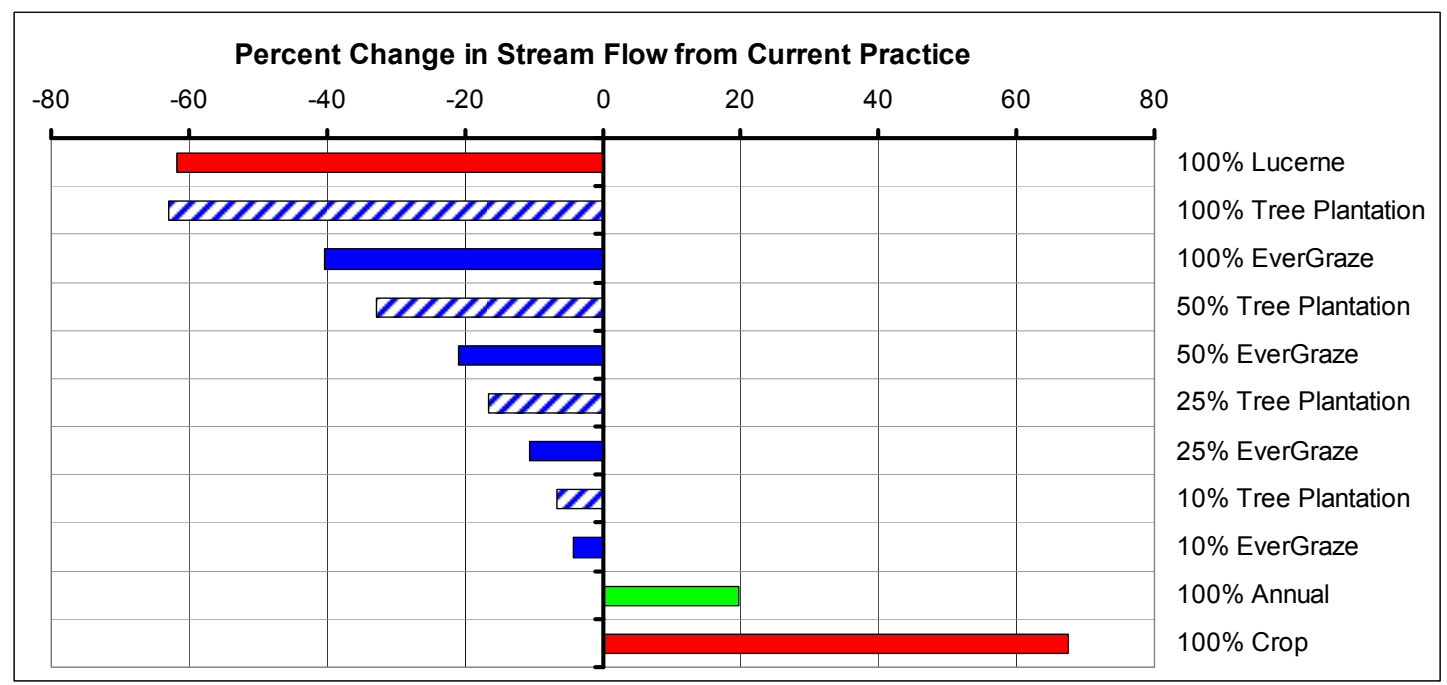

Figure 3 Gauge 238228 - Percentage change in stream flow relative to Current Practice

On average, the effect of tree planting is estimated to have approximately 1.5 times the influence of EverGraze adoption rates: This response was not uniform across the catchment with Tree Plantations having a much larger impact within the Basalt Plains due to the relatively smaller areas available for planting of Lucerne.

\subsection{Effect of EverGraze adoption rates on farm dams}

The consistency of available stock water was considered with different EverGraze adoption rates relative to current practice. Under current practice conditions, farm dams maintained a sufficient water volume for stock for $96 \%$ of months for the 53 year simulation period. The majority of months when farm dams were empty occurred within the last decade, due to dry conditions. With increasing EverGraze adoption the spatial area and the period of dry dams increase (Figure 4). However, only the $100 \%$ EverGraze option caused extended dry periods across multiple months. At a local level on specific farms, this extended dry period will be problematic to livestock grazing industry if they completely adopt a perennial grazing system.

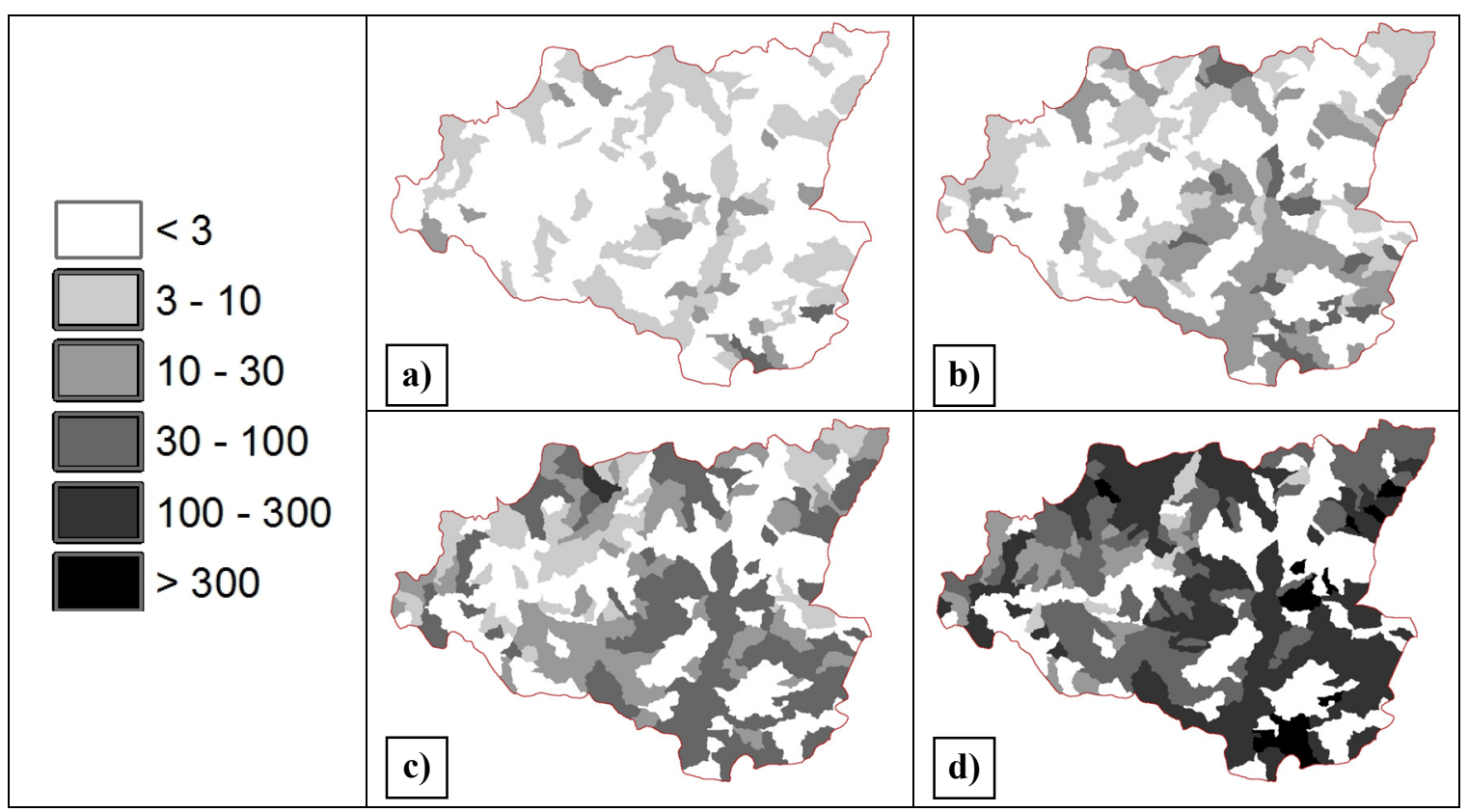

Figure 4. Percentage increase in months where dams are dry resulting from a) $10 \%$ EverGraze b) 255 EverGraze c) $50 \%$ EverGraze d) $100 \%$ EverGraze in the Wannon catchment (1957-2009) 
Christy et al., Changing land-use based on location in landscape affects catchment water yield.

\section{DISCUSSION AND CONCLUSIONS}

This paper used CATPlus to investigate the potential impacts of increasing catchment perenniality on stream flow and water bodies such as farm dams and wetlands.

Some of the key results of the paper were that:

- CATPlus was able to provide an adequate stream flow prediction over time. Improvement in prediction over this period was achieved through accounting for gaining and losing water stores along a stream reach including dams and wetlands;

- Increasing the perenniality of land-use, impacted stream flow and decreased catchment yield;

- The decrease in catchment water yield by tree plantations was 1.5 times that of EverGraze;

- An increase in the period when farm dams are dry only occurs in the Wannon catchment at higher levels of perennial adoption;

- The ability to use CATPlus to investigate these impacts provides an additional tool for policy and catchment managers to use in informing, understanding and prioritizing land use change at the catchment scale.

\section{ACKNOWLEDGMENTS}

The authors of this paper would like to acknowledge the financial support of the Future Farm Industries CRC which has enabled this research to be conducted.

\section{REFERENCES}

Avery A, Ssaul G, Sanford P, Behrendt R, Friend M, Mitchell M, Virgona J, Badgery W, Lodge G (2009) EverGraze - Rightplant, right place, right purpose. $50^{\text {th }}$ Annual conference of the grassland Society of Southern Australia, Ggeelong, Victoria, 6-7 August 2009, 59-68.

McMurray D (2004) Farm dam volume estimations from simple geometris relationships. Department of Water, Land and Biodiversity cservation, South Australia, Report no. DWLBC 2004/48.

Nash JE, Sutcliffe JV (1970) River flow forecasting through conceptual models part I - A discussion of principles. Journal of Hydrology 10, 282-290.

Nathan RJ, Crowe PA, Neal B (2004) The estimation of farm dam yield in small agricultural catchments in south eastern Australia. Australian Journal of Water Engineering 8(1) 21-35.

Weeks A, Christy B, Lowell K, Beverly C (2008) The Catchment Analysis Tool: demonstrating the benefits of interconnected biophysical models. In 'Landscape Analysis and Visualisation'. (Eds C Pettit, W Cartwright, I Bishop, K Lowell, D Pullar, D Duncan) pp. 49-71. (Springer-Verlag: Berlin). 